\title{
THE IMPACT OF CROP ON GHG EMISSIONS FROM CLAY SOILS: CASE STUDY OF LATVIA
}

\author{
*Anete Anna Zalite ${ }^{1}$, Jovita Pilecka-Ulcugaceva ${ }^{1}$, Kristine Valujeva ${ }^{1}$, Inga Grinfelde ${ }^{1}$, Sindija Liepa ${ }^{1}$, \\ Juris Burlakovs ${ }^{2}$, Zane Vincevica-Gaile ${ }^{3(\mathbb{D})}$ \\ ${ }^{1}$ Latvia University of Life Sciences and Technologies, Latvia \\ ${ }^{2}$ Estonia University of Life Sciences, Estonia \\ ${ }^{3}$ University of Latvia, Latvia \\ *Corresponding author's email: aneteannazalite@gmail.com
}

\begin{abstract}
Agriculture is a source of three primary GHG: $\mathrm{CO}_{2}, \mathrm{CH}_{4}$ and $\mathrm{N}_{2} \mathrm{O}$. In order to reduce agricultural GHG emissions, agricultural practices have to promote sustainable land management by helping to prevent soil erosion and creating the potential to increase soil carbon stock. Sustainable soil management includes reducing tillage and introducing legumes in crop rotation. The aim of the study is to identify the impacts of the soil tillage and the cultivated crops on formation of GHG emissions. The study site has 24 experimental fields where two types of soil tillage have been used and four crops where grown (wheat Triticum aestivum, rape Brassica napus, beans Vicia faba and barley Hordeum vulgare). Soil humidity, soil temperature and measurements of GHG emissions have been carried out during the plant vegetation period from 2018 to 2020. GHG emissions where measured using Picarro G2508. A total of 460 measurements of GHG emissions were made in 2018, 2019 and 2020. The minimum value of $\mathrm{N}_{2} \mathrm{O}$ emission is $-19.5 \mathrm{~g} \mathrm{ha}^{-1}$ day $^{-1}$, but the maximum is $273.4 \mathrm{~g} \mathrm{ha}^{-1}$ day $^{-1}$. $\mathrm{CH}_{4}$ emission has a minimum value of $-84.8 \mathrm{~g} \mathrm{ha}^{-1}$ day $^{-1}$, and a maximum of $514.1 \mathrm{~g} \mathrm{ha}^{-1} \mathrm{day}^{-1}$. The minimum value of $\mathrm{CO}_{2}$ emission is $-13.0 \mathrm{~kg} \mathrm{ha}^{-1} \mathrm{day}^{-1}$, but maximum of $1026.7 \mathrm{~kg} \mathrm{ha}^{-1}$ day ${ }^{-1}$. The results of $\mathrm{CO}_{2}, \mathrm{CH}_{4}$ and $\mathrm{N}_{2} \mathrm{O}$ emissions show a significant discrepancies between the arithmetic mean and the median values which indicates the observed extreme values. Kruskal-Wallis test showed statistically significant differences in GHG emissions by crop groups.
\end{abstract}

Key words: GHG emissions, crop production, soil tillage, agriculture GHG emissions.

\section{Introduction}

In line with the 17 Sustainable Development Goals set by the United Nations, the world population must be able to provide while reducing GHG emissions and reaching climate neutral economy. These objectives should be achieved through transforming existing approaches of farming practices (Sachs et al., 2019). Crop production occupies $12-14 \%$ of the available land area. Since 1961, the amount of food calories per capita has increased by about a third, while consumption of vegetable oils and meat has doubled. At the same time, the use of inorganic nitrogen fertiliser has grown nearly nine times (Arneth et al., 2019).

The development of the economy, including agricultural production, will inevitably lead to an increase in atmospheric GHG emissions. In order to reduce the environmental impact on agriculture, it is necessary to understand the effect of soil management and the role of soil in the context of GHG emissions (Valujeva et al., 2016; Valujeva, Nipers et al., 2020; Valujeva, Pilecka et al., 2020)increase in bio-based production is restricted by emission reduction targets set by climate policies. Meanwhile, the changes in Common Agricultural Policy after 2020 offer each Member State to develop targeted and regional specific policies to meet socio-economic and environmental targets at national scale. Sustainable land management requires understanding of trade-offs among multiple demands expecting from agriculture, land use, land use change and forestry sectors. Shifting from customary crops to crops with higher economic return can give immediate contribution to achieve socio economic targets, but at the same international commitments require maintenance of existing carbon stocks and increase of carbon sequestration capacity which can be achieved by changing farming practices. South-eastern region of Latvia is chosen as a relevant case study to show trade-offs between simultaneous increase in both bio-based production and carbon stock. The aim of the study is to find optimal approach for land use and improvements of management practices in south eastern region of Latvia to simultaneously increase bio based production and carbon stock. We use spatial land use model under different optimisation scenarios. Results show that production can be increased by $35.1 \%$, while carbon regulation function kept constant, but this rises another problem as it has a negative impact on the supply of biodiversity $(-9.2 \%$. Agriculture is a source of three primary GHG emissions: $\mathrm{CO}_{2}, \mathrm{CH}_{4}$ and $\mathrm{N}_{2} \mathrm{O}$. GHG emissions are caused by fermentation processes in the intestines of livestock, manure management, soil management, liming, use of urea. In Latvia, agriculture is the second largest sector behind energy, which contributes to GHG emissions, and soil management is the largest emitter of $\mathrm{N}_{2} \mathrm{O}$ emissions - 60.8\% (NIR, 2019). Agricultural soils are responsible for $18 \%$ of global GHG emissions (Ozlu et al., 2018). Soil emissions depend on the biophysical processes of the soil and the uptake and decomposition of organic substances in the soil. The 
main GHG sources are the use of organic and synthetic fertilisers. Nitrogen fertilisers are important for crop production, but the excessive use of fertilisers may increase GHG emissions. Inorganic fertilisers affect GHG emissions from soil, affecting microbial activity and root respiratory processes that affect nitrification and denitrification processes (Ozlu et al., 2018). High ground water levels, poor soil drainage properties and soil sealing contribute to denitrification and $\mathrm{N}_{2} \mathrm{O}$ formation (Bouwman et al., 2002). $\mathrm{CO}_{2}$ is produced under aerobic conditions and is affected by root activity, microbiological processes, plant residues, as well as microclimate, terrain and catalytic properties in coloid solutions of clay (Muñoz et al., 2010). In order to reduce GHG emissions from agriculture and their impact on global warming, agricultural practices need to ensure sustainable land management. Such practices include reducing soil tillage, which helps to prevent soil erosion and creates potential to increase soil carbon stock and can improve $\mathrm{CH}_{4}$ consumption (Johnson et al., 2007). Although agriculture generates a significant share of global GHG emissions, it can also contribute to climate change mitigation, as a crop rotation has the potential to reduce or at least not generate more GHG emissions from agriculture (Plaza-Bonilla et al., 2018). Introduction of crop rotation in agricultural lands is considered to be a good solution to increase carbon stock (Poeplau et al., 2015). In order to reduce nitrogen (N) losses in the environment and to reduce GHG emissions, alternative crop systems are promoted, assessing both the system and the culture to be cultivated (Autret et al., 2019). By carefully designing and following the rules of sustainable agricultural practice, the change in crop rotation containing legumes and cereals is rapidly reducing demand for $\mathrm{N}$ fertilisers (wheat by $13-30 \%$ ), without reducing wheat productivity or grain quality (Plaza-Bonilla et al., 2017). The cultivation of legume crops has been proposed as a way of reducing GHG emissions because they are able to deposit atmospheric $\mathrm{N}$ and thus reduce the need for external or other nitrogen fertilisers. On the other hand, the introduction of rapeseed in the crop rotation has a positive effect as it breaks the cycle of plant pathogens by reducing the need for pesticides to grow future crops (Vinzent et al., 2017). The formulation of GHG emissions depends on a number of factors that determine the amount of GHG emissions that occur at a particular type of management and need to be verified at national and regional scales (Oertel et al., 2016)methane (CH4. In Latvia, measurements of GHG emissions in the agricultural sector have been launched and are implemented in several directions. Firstly, research on GHG emission reduction measures and develops future scenarios for GHG emissions in Latvia (Kreismane et al., 2016; Lēnerts et al., 2016;
Lenerts, Berzins, \& Popluga, 2016; Lenerts, Popluga, \& Naglis-Liepa, 2019; Nipers, Pilvere, \& ZeverteRivza, 2017; Pilvere \& Lenerts, 2015; Zeverte-Rivza, Popluga, \& Berzina, 2017)and there is a large potential for land to be used in efficient agricultural production. National task is set for the next years in Latvia to retain agricultural land for agricultural production, in order to efficiently manage approximately 2 million ha. The agricultural sector is an important source of nitric oxide $(\mathrm{N}<\mathrm{inf}>2</$ inf $>\mathrm{O}$. Secondly, experimental studies are carried out on farms where $\mathrm{CH}_{4}$ measurements are carried out and solutions are sought to reduce $\mathrm{CH}_{4}$ emissions in the livestock sector (Berzina et al., 2017, 2018; Grinfelde et al., 2018; Jonova et al., 2018b, 2018a; Jonova, Ilgaza, \& Grinfelde, 2017)to measure the amount of methane (CH4. Thirdly, field and laboratory studies are being carried out to analyse not only GHG emissions from soil, but also to determine the effect of fertilizers on GHG emissions (Eihe et al., 2019, 2020; Frolova et al., 2017, 2018; Grinfelde et al., 2019). Currently, there is a lack of understanding of the impact of cultivated crops on GHG emissions in heavy clay soils, which occupy most of the Zemgale region, where mainly wheat and rapeseed are grown. The aim of this study is to identify the difference in GHG emissions by crop.

\section{Materials and Methods}

Measurements of GHG emissions were carried out in the experimental farm of Latvia University of Life Sciences and Technologies located at Platones parish of Jelgava municipality. The study site has 24 experimental fields where two types of soil tillage have been used (conventional soil tillage with mould-board ploughing at a depth of 22-24 cm and reduced soil tillage with disc harrowing at a depth below $10 \mathrm{~cm}$ ) and four crops where grown (wheat Triticum aestivum, rape Brassica napus, beans Vicia faba and barley Hordeum vulgare). Measurements of GHG emissions $\left(\mathrm{N}_{2} \mathrm{O}, \mathrm{CH}_{4}, \mathrm{CO}_{2}\right)$ in field conditions have been carried out on clay soil Cambic Calcisol according to IUSS Working Group WRB, (2015). Measurements of GHG emissions have been carried out in the growing season of 2018, 2019 and 2020. GHG measurements from agricultural soils were performed using a mobile spectrophotometer Picarro G2508, which allows simultaneous measurements of $\mathrm{N}_{2} \mathrm{O}, \mathrm{CH}_{4}$ and $\mathrm{CO}_{2}$ gases with an average interval of one second. Measurements were performed in three chambers for each study plot. Non-transparent chambers with a base diameter of $23 \mathrm{~cm}$ and a chamber volume of 3 litres were used. The base is made of metal, and its lower edge is sharpened to make it easier to place in the soil. A non-transparent dome is placed on the base (Frolova et al., 2018). The chamber's connections to the Picarro G2508 were made using commercially 
Table 1

Values for GHG emissions descriptive statistics

\begin{tabular}{|r|c|c|c|}
\hline Statistic & $\mathrm{N}_{2} \mathrm{O}, \mathrm{g} \mathrm{ha}^{-1} \mathrm{day}^{-1}$ & $\mathrm{CH}_{4}, \mathrm{~g} \mathrm{ha}^{-1}$ day $^{-1}$ & $\mathrm{CO}_{2}, \mathrm{~kg} \mathrm{ha}^{-1} \mathrm{day}^{-1}$ \\
\hline Nbr. of observations & 460 & 460 & 460 \\
\hline Nbr. of missing values & 0 & 0 & 0 \\
\hline Minimum & -19.5 & -84.8 & -13.0 \\
\hline Maximum & 273.4 & 514.1 & 1026.7 \\
\hline Range & 292.8 & 598.9 & 1039.8 \\
\hline Median & 0.0 & -0.4 & 23.1 \\
\hline Mean & 4.8 & 37.7 & 66.6 \\
\hline Variance (n) & 456.8 & 5398.3 & 10971.2 \\
\hline Standard deviation (n) & 21.4 & 73.5 & 104.7 \\
\hline
\end{tabular}

manufactured stainless steel connections. Soil moisture measurements were performed prior to soil GHG emissions measurements using the Lutron soil moisture meter PMS-714, which measures soil moisture at the surface of the soil. Air temperature measurements and air pressure measurements were carried out using barometric pressure gauge Diver DI 500, Eijkelkamp. The chamber's air temperature and air pressure meter was placed in the chamber just before the dome was secured. The measurement time was 400 seconds (Grinfelde et al., 2017; Valujeva et al., 2017). In order to transform the measurement of the concentration of Picarro G2508 into greenhouse gas emissions per hectare, the equation for the ideal gas position was used for the conversion of the emission factor to a concentration per day (Formula 1).

$$
F=p \cdot \frac{V}{A} \cdot \frac{\Delta c}{\Delta T} \cdot \frac{273}{T+273}, \text { where }
$$

$\mathrm{F}$ - emissions from soil $\left(\mathrm{g} \mathrm{ha}^{-1}\right.$ day $\left.^{-1}\right) ; \mathrm{p}$ - gas density in $\mathrm{mg} \mathrm{m} \mathrm{m}^{-3} ; \mathrm{V}$ - the volume of the chamber in $\mathrm{m}^{3}$; A - camera area $\mathrm{m}^{2} ; \Delta \mathrm{c} / \Delta \mathrm{T}$ - mean change in concentration at ppm s${ }^{-1} ; \mathrm{T}-$ camera temperature in ${ }^{\circ} \mathrm{C}$.

Descriptive statistics, box plots, and the KruskalWallis test have been used for data processing because the data do not correspond to the normal distribution, for data processing (Ruxton \& Beauchamp, 2008; Vargha \& Delaney, 1998) using XLSTAT software.

\section{Results and Discussion}

During the study period, a significant amplitude of GHG emission fluctuations is observed. Table 1 summarises the results of GHG measurements and gives an insight into $\mathrm{N}_{2} \mathrm{O}, \mathrm{CO}_{2}$ and $\mathrm{CH}_{4}$ statistics. A total of 460 observations were made in 2018, 2019 and 2020. The minimum value of $\mathrm{N}_{2} \mathrm{O}$ is $-19.5 \mathrm{~g} \mathrm{ha}^{-1}$ day $^{-1}$, maximum of $273.4 \mathrm{~g}$ $\mathrm{ha}^{-1}$ day $^{-1} \cdot \mathrm{CH}_{4}$ has a minimum value of $-84.8 \mathrm{~g}$ $\mathrm{ha}^{-1}$ day $^{-1}$, and a maximum of $514.1 \mathrm{~g} \mathrm{ha}^{-1}$ day $^{-1}$. The minimum value of $\mathrm{CO}_{2}$ is $-13.0 \mathrm{~g} \mathrm{ha}^{-1}$ day $^{-1}$, maximum of $1026.7 \mathrm{~g} \mathrm{ha}^{-1} \mathrm{day}^{-1}$. The results of all gas emissions measurements show a significant discrepancy between the arithmetic mean and the median values, indicating observed extreme values.

The next step is to analyse the differences in each GHG emission in the context of crops grown. Figure 1 shows the distribution of $\mathrm{N}_{2} \mathrm{O}$ emissions depending on the crop. The highest dispersion of $\mathrm{N}_{2} \mathrm{O}$ emission is observed from barley-grown soils, but the lowest from the beans. Extreme maximum values affecting the average values of emissions are observed for all crops, as well as extremely negative values for beans, wheat and rapeseed. The highest average $\mathrm{N}_{2} \mathrm{O}$ emission is formed by barley, while the lowest is formed by rapeseed. It appears that in the fields where beans were grown, a significant difference in $\mathrm{N}_{2} \mathrm{O}$ emissions was observed compared to the fields of rapeseed and barley. There is also a significant difference in $\mathrm{N}_{2} \mathrm{O}$

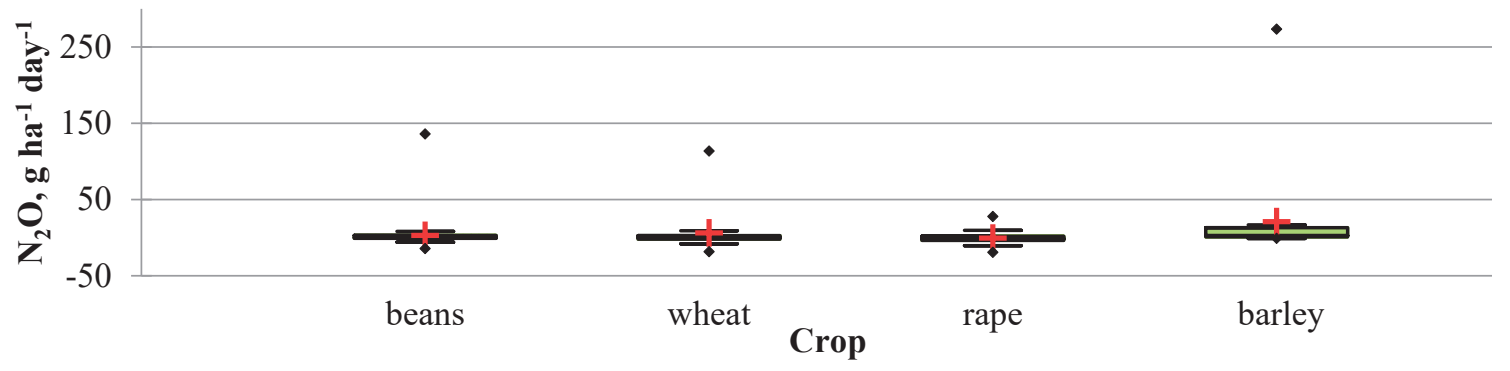

Figure $1 . \mathrm{N}_{2} \mathrm{O}$ emissions by crop groups. 
Table 2

Multiple pairwise comparisons using the Steel-Dwass-Critchlow-Fligner procedure / Two-tailed test

\begin{tabular}{|c|c|c|c|c|c|c|c|}
\hline & $\begin{array}{l}\mathrm{N}_{2} \mathrm{O}, \mathrm{g} \mathrm{ha}^{-1} \\
\text { day }^{-1} \mid \text { beans }\end{array}$ & $\begin{array}{l}\mathrm{N}_{2} \mathrm{O}, \mathrm{g} \mathrm{ha}^{-1} \\
\text { day }^{-1} \mid \text { wheat }\end{array}$ & $\begin{array}{l}\mathrm{N}_{2} \mathrm{O}, \mathrm{g} \mathrm{ha}^{-1} \\
\text { day }^{-1} \mid \text { rape }\end{array}$ & $\begin{array}{l}\mathrm{N}_{2} \mathrm{O}, \mathrm{g} \mathrm{ha}^{-1} \\
\text { day }^{-1} \mid \text { barley }\end{array}$ & \multicolumn{3}{|c|}{ Groups } \\
\hline $\mathrm{N}_{2} \mathrm{O}, \mathrm{g} \mathrm{ha}^{-1}$ day $^{-1} \mid$ beans & & 1.336 & 5.956 & -6.942 & A & & \\
\hline $\mathrm{N}_{2} \mathrm{O}, \mathrm{g} \mathrm{ha}^{-1}$ day $^{-1} \mid$ wheat & -1.336 & & 4.766 & -6.893 & & B & \\
\hline $\mathrm{N}_{2} \mathrm{O}, \mathrm{g} \mathrm{ha}^{-1}$ day $^{-1} \mid$ rape & -5.956 & -4.766 & & -8.756 & & B & \\
\hline $\mathrm{N}_{2} \mathrm{O}, \mathrm{g} \mathrm{ha}^{-1}$ day $^{-1} \mid$ barley & 6.942 & 6.893 & 8.756 & & & & $\mathrm{C}$ \\
\hline
\end{tabular}

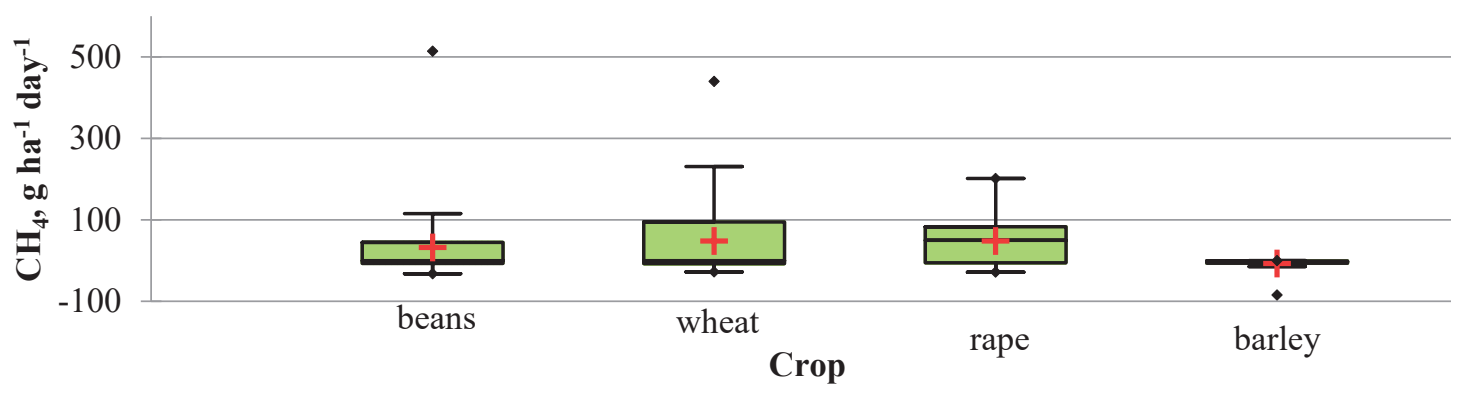

Figure 2. $\mathrm{CH}_{4}$ emissions of by crop groups.

emissions from wheat fields compared to rapeseed and barley. Barley from the perspective of $\mathrm{N}_{2} \mathrm{O}$, compared to other crops, produces significantly higher emissions, while rape-grown soils emit significantly lower emissions.

The independent samples Kruskal-Wallis test were used to test Null Hypothesis: The distribution of $\mathrm{N}_{2} \mathrm{O}$ emissions is the same for different crops. As the computed $\mathrm{p}$-value was lower than the significance level alpha $=0,05$, one should reject the null hypothesis, and accept the alternative hypothesis. The risk to reject the null hypothesis while it is true is lower than $0.01 \%$. Steel-Dwass-Critchlow-Fligner procedure was used to analyse the impact of differences between crops on $\mathrm{N}_{2} \mathrm{O}$ emissions (Table 2).

The distribution of $\mathrm{CH}_{4}$ emissions by crop groups is shown in Figure 2. The largest distribution of $\mathrm{CH}_{4}$ emissions has been observed from wheat-grown soils, while the smallest for barley, where extreme negative values have also been observed. Value of $\mathrm{CH}_{4}$ emissions depending on the crop grown. It appears that the only culture that has a significant impact on $\mathrm{CH}_{4}$ emissions compared to other crops is barley. In all three options, emissions have decreased. For other crops, the average values of $\mathrm{CH}_{4}$ do not differ significantly.

The independent samples Kruskal-Wallis test were used to test Null Hypothesis: The distribution of $\mathrm{CH}_{4}$ emissions is the same for different crops. As the computed p-value was lower than the significance level alpha $=0.05$, one should reject the null hypothesis, and accept the alternative hypothesis. The risk to reject the null hypothesis while it is true is lower than $0.01 \%$. The Steel-Dwass-Critchlow-Fligner procedure was used to analyse the effect of differences between crops on $\mathrm{CH}_{4}$ emissions (Table 3).

Table 3

Multiple pairwise comparisons using the Steel-Dwass-Critchlow-Fligner procedure / Two-tailed test

\begin{tabular}{|c|c|c|c|c|c|c|}
\hline & $\begin{array}{l}\mathrm{CH}_{4}, \mathrm{~g} \mathrm{ha}^{-1} \\
\text { day }^{-1} \mid \text { beans }\end{array}$ & $\begin{array}{l}\mathrm{CH}_{4}, \mathrm{~g} \mathrm{ha}^{-1} \\
\text { day }^{-1} \mid \text { wheat }\end{array}$ & $\begin{array}{l}\mathrm{CH}_{4}, \mathrm{~g} \mathrm{ha}^{-1} \\
\text { day }^{-1} \mid \text { rape }\end{array}$ & $\begin{array}{l}\mathrm{CH}_{4}, \mathrm{~g} \mathrm{ha}^{-1} \\
\text { day }^{-1} \mid \text { barley }\end{array}$ & \multicolumn{2}{|c|}{ Groups } \\
\hline $\mathrm{CH}_{4}, \mathrm{~g} \mathrm{ha}^{-1}$ day $^{-1} \mid$ beans & & -1.375 & -3.419 & 4.580 & A & \\
\hline $\mathrm{CH}_{4}, \mathrm{~g} \mathrm{ha}^{-1}$ day $^{-1} \mid$ wheat & 1.375 & & -1.262 & 5.037 & & $\mathrm{~B}$ \\
\hline $\mathrm{CH}_{4}, \mathrm{~g} \mathrm{ha}^{-1}$ day $^{-1} \mid$ rape & 3.419 & 1.262 & & 6.400 & & $\mathrm{~B}$ \\
\hline $\mathrm{CH}_{4}, \mathrm{~g} \mathrm{ha}^{-1}$ day $^{-1} \mid$ barley & -4.580 & -5.037 & -6.400 & & & $\mathrm{~B}$ \\
\hline
\end{tabular}




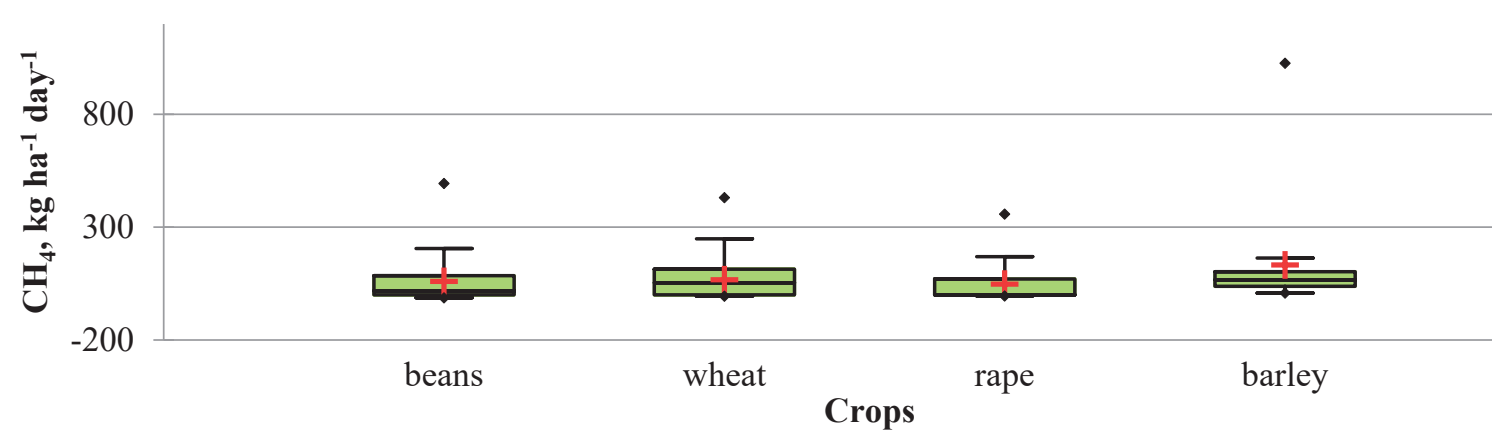

Figure 3. $\mathrm{CO}_{2}$ emission by crop groups.

Table 4

Multiple pairwise comparisons using the Steel-Dwass-Critchlow-Fligner procedure / Two-tailed test

\begin{tabular}{|c|c|c|c|c|c|c|}
\hline & $\begin{array}{l}\mathrm{CO}_{2}, \mathrm{~kg} \mathrm{ha}^{-1} \\
\text { day }^{-1} \mid \text { beans }\end{array}$ & $\begin{array}{l}\mathrm{CO}_{2}, \mathrm{~kg} \mathrm{ha}^{-1} \\
\text { day }^{-1} \mid \text { wheat }\end{array}$ & $\begin{array}{c}\mathrm{CO}_{2}, \mathrm{~kg} \mathrm{ha}^{-1} \\
\text { day }^{-1} \mid \text { rape }\end{array}$ & $\begin{array}{l}\mathrm{CO}_{2}, \mathrm{~kg} \mathrm{ha}^{-1} \\
\text { day }^{-1} \mid \text { barley }\end{array}$ & \multicolumn{2}{|c|}{ Groups } \\
\hline $\mathrm{CO}_{2}, \mathrm{~kg} \mathrm{ha}^{-1}$ day $^{-1} \mid$ beans & & -1.366 & 1.114 & -5.568 & A & \\
\hline $\mathrm{CO}_{2}, \mathrm{~kg} \mathrm{ha}^{-1}$ day $^{-1} \mid$ wheat & 1.366 & & 2.172 & -3.517 & A & \\
\hline $\mathrm{CO}_{2}, \mathrm{~kg} \mathrm{ha}^{-1}$ day $^{-1} \mid$ rape & -1.114 & -2.172 & & -7.162 & A & B \\
\hline $\mathrm{CO}_{2}, \mathrm{~kg} \mathrm{ha}^{-1}$ day $^{-1} \mid$ barley & 5.568 & 3.517 & 7.162 & & & B \\
\hline
\end{tabular}

Figure 3 shows the distribution of $\mathrm{CO}_{2}$ emissions depending on the crop. Large scatter and extreme values of $\mathrm{CO}_{2}$ emissions have been observed for all crops. The highest average value was observed from the soils where barley was grown - 307.261 kg ha-1 day $^{-1}$, while the lowest average value of $\mathrm{CO}_{2}$ emissions was observed in the rapeseed fields - $205.796 \mathrm{~kg}$ $\mathrm{ha}^{-1}$ day $^{-1}$. There is no significant difference between beans, wheat and rapeseed in the formation of $\mathrm{CO}_{2}$ emissions. Barley has been reported to produce emissions of $5.568 \mathrm{~kg} \mathrm{ha}^{-1}$ day $^{-1}$ higher than beans and $7.162 \mathrm{~g} \mathrm{ha}^{-1}$ day $^{-1}$ higher than rapeseed with a significant difference.

The independent samples Kruskal-Wallis test were used to test Null Hypothesis: The distribution of $\mathrm{CO}_{2}$ emissions is the same for different crops. As the computed p-value was lower than the significance level alpha $=0.05$, one should reject the null hypothesis, and accept the alternative hypothesis. The risk to reject the null hypothesis while it is true is lower than $0.01 \%$. Steel-Dwass-Critchlow-Fligner procedure was used to analyse the impact of differences between crops on $\mathrm{CO}_{2}$ emissions (Table 4).

\section{Conclusions}

The results of the three-year studies show a significant variability in GHG emissions, especially the extreme values for $\mathrm{N}_{2} \mathrm{O}$ emissions, which reach of $273.4 \mathrm{~g} \mathrm{ha}^{-1}$ day $^{-1}$. Analysing GHG emissions from clay soils by crop groups, the Kruskal-Wallis test shows a statistically significant difference in the effect of cultivated crops on GHG emissions. $\mathrm{N}_{2} \mathrm{O}$ emissions showed a statistically significant difference between crop groups. Barley has a significant effect on $\mathrm{CH}_{4}$ emissions compared to other crops. In future studies, it is necessary to increase the number of plots where measurements are made and the number of measurements by in-depth study of plots where barley is grown. An analysis of the effect of preculture on GHG emissions from clay soils is required.

\section{Acknowledgments}

The research were funded by Ministry of Agriculture, Republic Latvia, "Development of a system of greenhouse gas (GHG) emissions and carbon dioxide $(\mathrm{CO} 2)$ removal from arable land and permanent grassland management and development of appropriate methodological solutions" Nr.19-00SOINV05-000019 and Nr.20-00-SOINV05-000007.

\section{References}

Arneth, A.F., Denton, F., Agus, A., Elbehri, K., Erb, B., Osman Elasha, M., ... Spence, R., Valentini (2019). Framing and Context. In: Climate Change and Land: an IPCC special report on climate change, desertification, land degradation, sustainable land management, food security, and greenhouse gas fluxes in terrestrial ecosystems [P.R. Shukla, J. Skea, E. Calvo Buendia, V. Masson-Delmotte, H.-O. Pörtner, D.C. 
Roberts, P. Zhai, R. Slade, S. Connors, R. van Diemen, M. Ferrat, E. Haughey, S. Luz, S. Neogi, M. Pathak, J. Petzold, J. Portugal Pereira, P. Vyas, E. Huntley, K. Kissick, M. Belkacemi, J. Malley, (eds.)]. In press.

Autret, B., Beaudoin, N., Rakotovololona, L., Bertrand, M., Grandeau, G., Gréhan, E., Ferchaud, F., \& Mary, B. (2019). Can alternative cropping systems mitigate nitrogen losses and improve GHG balance? Results from a 19-yr experiment in Northern France. Geoderma. Vol. 342, pp. 20-33.

Bouwman, A.F., Boumans, L.J.M., \& Batjes, N.H. (2002). Emissions of N2O and NO from fertilized fields: Summary of available measurement data. Global Biogeochemical cycles. 16(4), 6-1, 6-13.

Berzina, L., Frolova, O., Grinfelde, I., \& Valujeva, K. (2017). Greenhouse gases and ammonia emission evaluation of conventional and organic dairy farming in Baltic region. In International Multidisciplinary Scientific GeoConference Surveying Geology and Mining Ecology Management. 29 June - 5 July, 2017 (pp. 449-458), Sofia, Bulgaria: SGEM. DOI: 10.5593/sgem2017/41/S19.057.

Berzina, L., Grinfelde, I., Frolova, O., Karina, Z., \& Pilecka, J. (2018). Tool of consistent reporting of GHG and air pollutant emissions: Case study of Latvia's agricultural sector. In International Multidisciplinary Scientific GeoConference Surveying Geology and Mining Ecology Management. 02-08 July, 2018 (pp. 703-710), Sofia, Bulgaria: SGEM. DOI: 10.5593/sgem2018/4.2/S19.090.

Eihe, P., Grinfelde, I., Pilecka, J., Valujeva, K., \& Vebere, L.L. (2020). The impact of soil treatment and moisture regime on $\mathrm{N} 2 \mathrm{O}$ emissions from agricultural soil. In International Multidisciplinary Scientific GeoConference Surveying Geology and Mining Ecology Management. 2020 August (pp. 515-522). Sofia, Bulgaria: SGEM. DOI: 10.5593/sgem2020/4.1/s19.064.

Eihe, P., Vebere, L.L., Grinfelde, I., Pilecka, J., Sachpazidou, V., \& Grinberga, L. (2019). The effect of acidification of pig slurry digestate applied on winter rapeseed on the ammonia emission reduction. In IOP Conference Series: Earth and Environmental Science. 7-9 October, 2019 (Vol. 390). Gdansk, Poland: IOP Publishing Ltd. DOI: 10.1088/1755-1315/390/1/012043.

Frolova, O., Grinfelde, I., Berzina, L., Valujeva, K., \& Pilecka, J. (2018). Soil moisture impact on ammonia soil fluxes with input of mineral nitrogen. In International Multidisciplinary Scientific GeoConference Surveying Geology and Mining Ecology Management. 02-08 July, 2018 (pp. 607-614). Sofia, Bulgaria: SGEM. DOI: 10.5593/sgem2018/4.2/S19.078.

Frolova, O., Grinfelde, I., Kalnina, R., Berzina, L., \& Valujeva, K. (2018). The chamber configuration impact on soil flux precision using cavity ring-down spectroscopy. In International Multidisciplinary Scientific GeoConference Surveying Geology and Mining Ecology Management. 02-08 July, 2018 (pp. 623-629). Sofia, Bulgaria: SGEM. DOI: 10.5593/sgem2018/4.2/S19.080.

Frolova, O., Zaharane, K., Grinfelde, I., Valujeva, K., \& Berzina, L. (2017). The measurements of direct $\mathrm{N} 2 \mathrm{O}$ and $\mathrm{NH} 3$ emissions from nitrogen fertilizers application in laboratory conditions. In International Multidisciplinary Scientific GeoConference Surveying Geology and Mining Ecology Management. 29 June-05 July, 2017 (pp. 659-664). Sofia, Bulgaria: SGEM. DOI: 10.5593/sgem2017/41/S19.082.

Grinfelde, I., Ilgaza, A., Jonova, S., Arne, A., \& Kovalenko, K. (2018). Inulin impact on co2 and ch4 balance in holstein friesian crossbreed calves rumen. In International Multidisciplinary Scientific GeoConference Surveying Geology and Mining Ecology Management. 02-08 July, 2018 (pp. 507-513). Sofia, Bulgaria: SGEM. DOI: 10.5593/sgem2018/4.2/S19.066.

Grinfelde, I., Pilecka, J., Berzina, L., Eihe, P., \& Valujeva, K. (2019). The ammonia emission reduction effect of acidification of pig slurry digestate applied on winter wheat. In International Multidisciplinary Scientific GeoConference Surveying Geology and Mining Ecology Management. 30 June - 6 July, 2019 (pp. 11011108). Sofia, Bulgaria: SGEM. DOI: 10.5593/sgem2019/4.1/S19.140.

Grinfelde, I., Valujeva, K., Zaharane, K., \& Berzina, L. (2017). Automated cavity ring down spectroscopy usage for nitrous oxide emission measurements from soil using recirculation system. In Engineering for Rural Development. Vol. 16, pp. 1111-1116. DOI: 10.22616/ERDev2017.16.N235.

IUSS Working Group WRB. (2015). World Reference Base for Soil Resources 2014, update 2015 International soil classification system for naming soils and creating legends for soil maps. Rome: World Soil Resources Reports No. 106. FAO.

Jonova, S., Ilgaza, A., \& Grinfelde, I. (2017). Methane mitigation possibilities and weight gain in calves fed with prebiotic inulin. In Research for Rural Development. Vol. 1, pp. 265-270. DOI: 10.22616/rrd.23.2017.039.

Jonova, S., Ilgaza, A., Grinfelde, I., \& Zolovs, M. (2018). Impact of inulin on production of methane, carbon dioxide and gastrointestinal canal functionality in calves. In Research for Rural Development. Vol. 1, pp. 264-270. DOI: 10.22616/rrd.24.2018.042.

Jonova, S., Ilgaza, A., Grinfelde, I., \& Zolovs, M. (2018). Impact of the flour of Jerusalem artichoke on the production of methane and carbon dioxide and growth performance in calves. Veterinary World, 11(11), 1532-1538. DOI: 10.14202/vetworld.2018.1532-1538. 
Johnson, J.M.F., Franzluebbers, A.J., Weyers, S.L., \& Reicosky, D.C. (2007). Agricultural opportunities to mitigate greenhouse gas emissions. Environmental Pollution. Vol. (150), 107-124. DOI: 10.1016/j. envpol.2007.06.030.

Kreismane, D., Naglis-Liepa, K., Popluga, D., Lenerts, A., \& Rivza, P. (2016). Liming effect on nitrogen use efficiency and nitrogen oxide emissions in crop farming. In Research for Rural Development. Vol. (1), 30-36.

Lenerts, A., Berzins, G., \& Popluga, D. (2016). Nitrogen fertilizer use efficiency and GHG emissions in the Latvian grain sector. In Engineering for Rural Development. Vol. (2016-Janua), pp. 224-229.

Lenerts, A., Popluga, D., \& Naglis-Liepa, K. (2019). Benchmarking the GHG emissions intensities of crop and livestock-derived agricultural commodities produced in Latvia. Agronomy Research, 17(5), 1942-1952. DOI: $10.15159 /$ AR.19.148.

Lēnerts, A., Popluga, D., Naglis-Liepa, K., \& Rivža, P. (2016). Fertilizer use efficiency impact on GHG emissions in the Latvian crop sector. Agronomy Research, 14(1), 123-133.

Munoz, C., Paulino, L., Monreal, C., \& Zagal, E., (2010). Greenhouse gas (CO2 and N2O) emissions from soils: A review. Chilean Journal of Agricultural Research. 70(3), 485-497.

Nipers, A., Pilvere, I., \& Zeverte-Rivza, S. (2017). Projections for the Latvian dairy and beef sector. In Engineering for Rural Development. Vol. 16, pp. 546-554. DOI: 10.22616/ERDev2017.16.N108.

NIR (2019). Latvia's National Inventory Report Submission under UNFCCC and the Kyoto Protocol 19902017. Retrieved February 16, 2021, from https:/unfccc.int/documents/194812.

Oertel, C., Matschullat, J., Zurba, K., Zimmermann, F., \& Erasmi, S. (2016). Greenhouse gas emissions from soils-A review. Chemie Der Erde, 76(3), 327-352. DOI: 10.1016/j.chemer.2016.04.002.

Ozlu, E., \& Kumar, S. (2018). Response of surface GHG fluxes to long-term manure and inorganic fertilizer application in corn and soybean rotation. Science of the Total Environment. Vol. 626, pp. 817-825.

Pilvere, I., \& Lenerts, A. (2015). Agricultural GHG emission and mitigation measures in Latvia. In Engineering for Rural Development Vol. 14, pp. 571-576.

Plaza-Bonilla, D., Nogué-Serra, I., Raffaillac, D., Cantero-Martínez, C., \& Justes, É. (2018). Carbon footprint of cropping systems with grain legumes and cover crops: A case-study in SW France. Agricultural Systems. Vol. 167, 92-102.

Plaza-Bonilla, D., Nolot, J.M., Raffaillac, D., \& Justes, E. (2017). Innovative cropping systems to reduce N inputs and maintain wheat yields by inserting grain legumes and cover crops in southwestern France. European Journal of Agronomy. 82 Part B, 332-341.

Poeplau, C., Bolinder, M.A., Eriksson, J., Lundblad, M., \& Kätterer, T., (2015). Positive trends in organic carbon storage in Swedish agricultural soils due to unexpected socio-economic drivers, Biogeosciences. Vol. 12, p. 3241-3251, DOI: 10.5194/bg-12-3241.

Ruxton, G.D., \& Beauchamp, G. (2008). Some suggestions about appropriate use of the Kruskal-Wallis test. Animal Behaviour, 76(3), 1083-1087. DOI: 10.1016/j.anbehav.2008.04.011.

Sachs, J.D., Schmidt-Traub, G., Mazzucato, M., Messner, D., Nakicenovic, N., \& Rockström, J. (2019). Six Transformations to Achieve the Sustainable Development Goals. Nature Sustainability, 2(9), 805-814. DOI: $10.1038 / \mathrm{s} 41893-019-0352-9$.

Valujeva, K., Nipers, A., Lupikis, A., \& Schulte, R.P.O. (2020). Assessment of Soil Functions: An Example of Meeting Competing National and International Obligations by Harnessing Regional Differences. Frontiers in Environmental Science, 8. DOI: 10.3389/fenvs.2020.591695.

Valujeva, K., O’Sullivan, L., Gutzler, C., Fealy, R., \& Schulte, R.P.O. (2016). The challenge of managing soil functions at multiple scales: An optimisation study of the synergistic and antagonistic trade-offs between soil functions in Ireland. Land Use Policy, 58, 335-347. DOI: 10.1016/j.landusepol.2016.07.028.

Valujeva, K., Pilecka, J., Frolova, O., Berzina, L., \& Grinfelde, I. (2017). Measurement time estimation of $\mathrm{CO} 2, \mathrm{CH} 4, \mathrm{~N} 2 \mathrm{O}$ and $\mathrm{NH} 3$ in closed chambers and recirculation system with picarro g2508 analyser. In International Multidisciplinary Scientific GeoConference Surveying Geology and Mining Ecology Management. 29 June - 05 July, 2017 (pp. 519-526), Sofia, Bulgaria: SGEM. DOI: 10.5593/sgem2017/41/ S19.066.

Valujeva, K., Pilecka, J., Grinfelde, I., \& Nipers, A. (2020). Optimisation of land use for improved soil based ecosystem services: An example from Latvia. In International Multidisciplinary Scientific GeoConference Surveying Geology and Mining Ecology Management. 18-24 August, 2020 (pp. 479-485). Sofia, Bulgaria: SGEM. DOI: 10.5593/sgem2020/3.1/s13.062.

Vargha, A., \& Delaney, H.D. (1998). The Kruskal-Wallis Test and Stochastic Homogeneity. Journal of Educational and Behavioral Statistics, 23(2), 170-192. DOI: 10.3102/10769986023002170. 
Vinzent, B., Fußb, R., Maidla, F.X., \& Hülsbergena, K.J. (2017). Efficacy of agronomic strategies for mitigation of after-harvest N2O emissions of winter oilseed rape. European Journal of Agronomy, Vol. 89, pp. 88-96.

Zeverte-Rivza, S., Popluga, D., \& Berzina, L. (2017). Evaluation of risks in agriculture in the context of climate change. In International Multidisciplinary Scientific GeoConference Surveying Geology and Mining Ecology Management. 29 June - 05 July, 2017 (pp. 417-424). Sofia, Bulgaria: SGEM. DOI: 10.5593/ sgem2017/41/S19.053. 